\title{
THE EFFECT OF ANTICHOLINERGIC DRUGS ON THE CARDIAC VAGUS: I, CLINICCAL OBSERVATIONS IN PATIENTS UNDERGOING ELECTROSHOCK TREATMENT ${ }^{1}$
}

\author{
Alzen B. Dobkin, M.D. ${ }^{2}$
}

THE EFFECT of anticholinergic drugs on the human cardiac vagus is difficult to demonstrate under clinical conditions, and was therefore not included in previous studies of these drugs on volunteers (1). However, mentally disturbed patients receiving electroshock treatment (ECT) might be suitable subjects for such a study. This idea was based on the observation that ECT is followed by vagal hyperactivity $(2,3,4)$. This powerful vagal stimulus may be sufficient to cause cardiac asystole. This condition occurred once at this hospital, and has been reported by others (5-9).

\section{Methods and Materials}

Observations were made during 396 treatments on 66 patients, varying in age from 21 to 76 years. Each patient received ECT in the morning while fasting. An oral airway was inserted just before ECT. Oxygen was administered immediately after the shock with a bag and mask' by controlled intermittent positive pressure breathing until respiratory efforts by the patient were considered adequate. Direct observation of the electrocardiogram recording, palpation of the radial pulse, and ausculation of the apical heart beat were studied: (i) during unmodified shock therapy in 8 unpremedicated patenfs; (ii) during modified shock treatment in 32 unpremedicated patients; and (iii) in 52 premedicated patients during 356 modified shock treatments. "Premedication" refers to the prior administration of an anticholinergic or antihistaminic drug. "Modified" refers to the administration of an ultra-short-acting barbiturate and a muscle relaxant intravenously immediately preceding ECT. For each patient the electroshock was applied to the head by a line voltage of approximately $115 \mathrm{v}$. lasting between 0.8 and 1.2 sec.- The current was delivered by a simple electrical stimulator similar to that originally described by Cerletti and Bini.

Monitoring of the arterial and venous blood pressure directly was not deemed feasible in these mentally disturbed patients, and was therefore not carried out, although it was recognized that ECT causes marked alterations (10). The electrocardiogram (lead 2) was recorded in most patients on a direct-writing Sanborn Visocardiette and in the remaining patients on an oscilloscope with photographic recorder. In the first group ( 8 patients) the electrocardiograph recording was taken continuously from a few minutes preceding the shock until after the convulsion and a normal record was apparent. In the second group (32'patients), the electrocardiograph recording was started just before injection of thiopental (75-150 mg.)

\footnotetext{
1Presented at the Annual Meeting of the Canadian Anaesthetists' Society, June 23-25, 1958.

2From the Departments of Anaesthesia and Psychiatry, University Hospital, and University of Saskatchewan College of Medicine, Saskatoon, Saskatchewan.
} 
and succinylcholine (10-20 mg.). In the third group, 18 of the 52 patients were among those in the second group. These 18 patients received each of 8 drugs under study at least once intravenously: atropine 0.6-1 mg., scopolamine 0.2-0.4 mg., l'hyoscyamine $0.3 \mathrm{mg}$. (Bellafoline ${ }^{\circledR}$ ), oxyphenoniurn $0.5 \mathrm{mg}$. (Antrenyl ${ }^{\circledR}$ ), hexocyclium $1.5 \mathrm{mg}$. (Tral ${ }^{\circledR}$ ), methantheline $5-15 \mathrm{mg}$. (Banthine ${ }^{\circledR}$ ), promethazine $25 \mathrm{mg}$. (Phenergan ${ }^{(1)}$ ), and mepazine $25 \mathrm{mg}$. (Pacatal $\left.{ }^{(1)}\right)$. Following a control electrocardiogram, premedication was injected. Then, 5 min. Iater by the clock, the electrocardiogram wass recorded continuously during injection of thiopental and succinylcholine and until a normal record was apparent after the ECT. The remaining 34 patients in this group were given premedication intramuscularly $30 \mathrm{~min}$. before the treatment. Most of the latter received two or three of the above drugs on at least three occasions. In these patients the electrocardiogram was recorded continuously as above.

Palpation of the radial pulse was carried out during the times that electrocardiograph recordings were taken. In the older patients, and whenever feasible, the apex beat of the heart was observed by auscultation.

\section{Observations}

\section{Clinical Reactions}

Three responses were observed $(11,12)$

No reaction. The patient had a sudden start, with the onset of the current flow. Unconsciousness was caused by the shock and was of brief duration (a few seconds). This type of reaction was seen with only'six treatments in five patients. When no reaction occurred, additional shocks were given ( two or three) in order to produce a convulsion. In each of these patients, only a minor or an abortive convulsion was produced.

Abortive convulsion. A sudden start, as above, was followed in a few seconds by slight twitching of the face, hands, and feet, and tonic spasm of the neck muscles. Slight to moderate cyanosis of the face and neck often appeared after the onset of twitching. The fingers usually assumed a characteristic fist position with the thumb between the index and middle fingers. The feet were usually extended. The patient's colour improved during artificial respiration (for 1 to 5 min.) with 100 per cent oxygen. Breathing began quietly in most patients. This type of reaction was seen during thirty-one treatments in fourteen of the patients. It is seen more frequently when larger doses of muscle relaxants are administered to modify ECT.

Grand mal convulsion. A severe generalized tonic spasm lasting several seconds was followed by facial twitching, marked flexor tonus of the hands and feet, and upward deviation of the eyes. The reaction then gave way to coarse clonic movements. The convulsion usually lasted 30 to $65 \mathrm{sec}$. Apnoea lasted a minute or two longer than the convulsion, while unconsciousness usually exceeded 3 min. Slight cyanosis appeared in almost all the patients following one or more of their treatments. This type of reaction was seen during 365 treatments in the fifty-two patients. 


\section{Cardiovascular Reactions}

Unpremedicated patients and unmodified shock ( 8 treatments). The reactions began with a tonic seizure lasting 3 to 16 sec., followed by a clonic seizure of from 20 to $50 \mathrm{sec}$. The clonic seizure was followed by marked restlessness. Unconsciousness was induced immediately by the electroshock and lasted until 1 to $3 \mathrm{~min}$. after the seizure subsided. As consciousness was regained, there was a period in which the patient was very confused and threshed about.

The physical reaction was so severe that the electrocardiograms were grossly obscured by the skeletal muscle action currents. The only consistent and valid observation was elevation of the $\mathrm{P}$ and $\mathrm{T}$ waves. Strong flexion of the wrists obscured the radial pulse in every patient. Auscultation of the heart during four of the eight treatments indicated the occurrence of a period of asystole which lasted until the clonic convulsion began.

Unpremedicated patients and modified shock (32 treatments). On the electrocardiogram it appeared as if a period of cardiac asystole may have occurred in every patient. Initially, the asystole was felt to be due entirely to an artifact caused by the electric current (applied to the patient) "shocking" the electrocardiographic recorder. However, auscultation of the heart in fourteen, and palpation of the radial pulse in all thirty-two patients, appeared to provide valid proof that immediately following the passage of the electric current, and corresponding approximately to the tonic phase of the shock, there was a period of a few

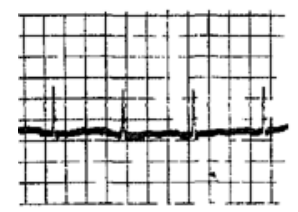

CONTROL

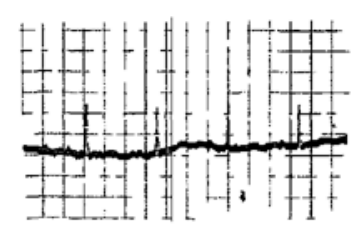

5 minuter ofted 0 ong Alr xpine
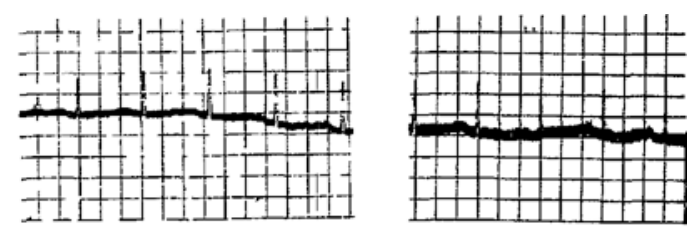

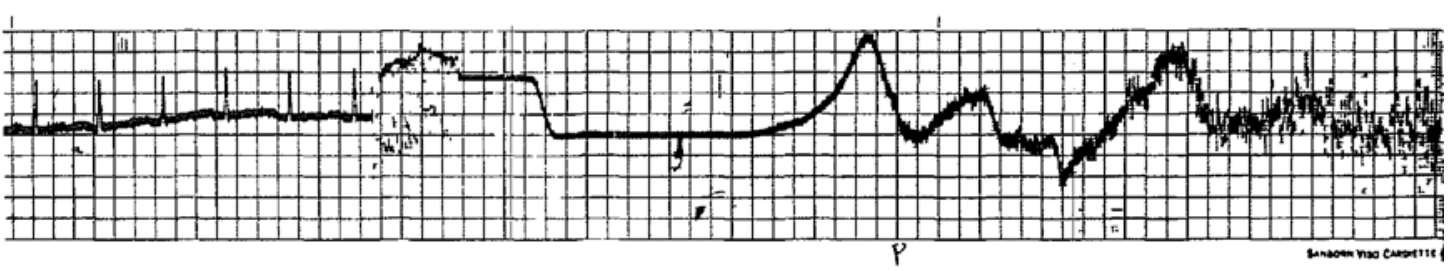

17 reconde

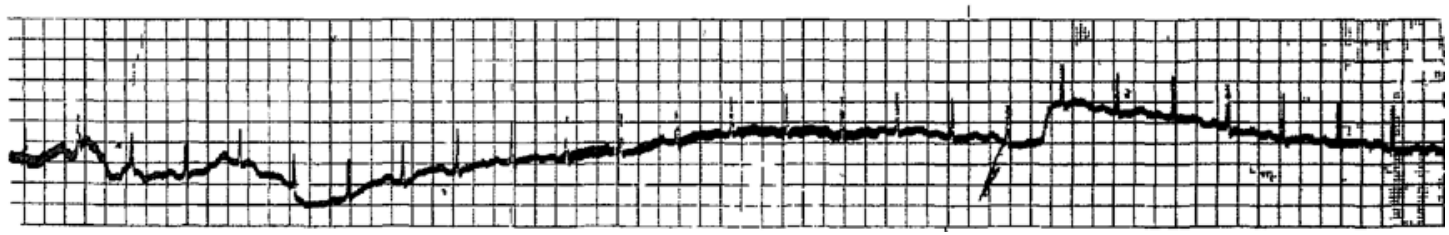

Frgure 1. Female, aged 48 years, under treatment for chronic schizophrenia. No history or clinical evidence of cardiovascular disease. Premedicated with $06 \mathrm{mg}$. of atropine i.v. Modified ECT with 115 v. for 0,9 sec. No cyanosis developed during grand mal convulsion. Pulse was not palpable for $3 \%$ sec. after shock. Elevated $\mathrm{P}$ and $\mathrm{T}$ waves and tachycardia for next 21 sec. Normal record thereafter. 
seconds when there was no heart beat. In eleven of these patients it was noted also that, in spite of ventilating the lungs with 100 per cent oxygen immediately following the shock, they became cyanotic. In three of these patients, cyanosis was marked, and required vigorous artificial respiration for several minutes before good colour returned. In these three patients, the heart beat could not be heard by auscultation for more than 10 sec.

In most of these patients the radial pulse became palpable a moment before the clonic phase of the convulsion began. The rate of the palpable pulse at this time was usually much increased. Shortly thereafter, cardiac complexes could be discerned on the electrocardiogram. These appeared grossly irregular in form. As the clonic convulsion subsided, the electrocardiogram became clearer and approached a normal form.

At subsequent study of the portion of the electrocardiograph tracing taken during the convulsion, critical interpretation was unreliable because action currents of skeletal muscle contractions masked the cardiac action currents. It was evident, however, that gross irregularities were present, and that alterations in cardiac rate and rhythm persisted in most patients until spontaneous respiration was adequate.

Premedicated patients and modified shock (356 treatments). These patients received eight to twelve treatments, at two-day intervals over a two- to three-week period. Serial observations on this group indicated that the gross disturbances on the electrocardiograph tracings induced by the electroshock were less severe and

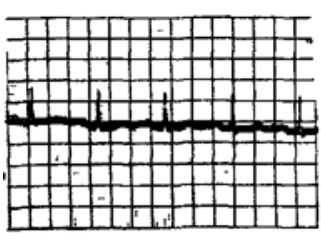

cONmol

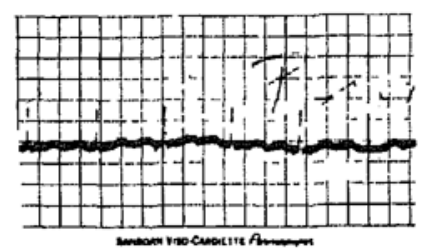

I minuw dive 125me Thlopentol

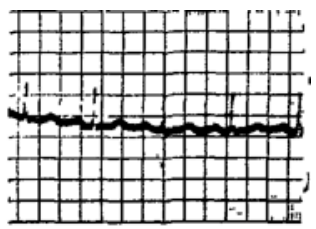

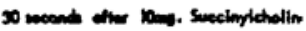

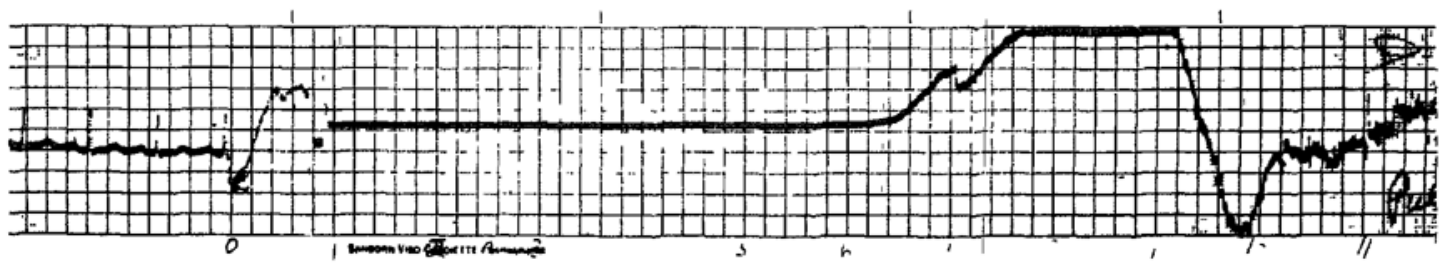

20 meond
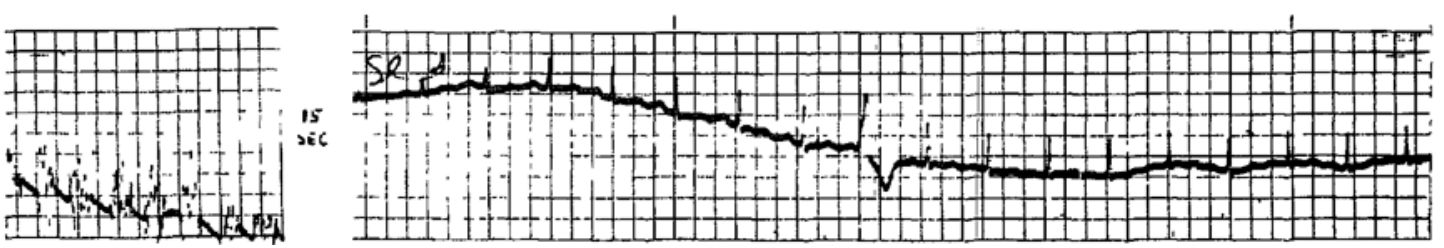

Figure 2. Same patient as in Figure 1, 2 days later. No premedication. Modified ECT with $115 \mathrm{v}$. for $0.9 \mathrm{sec}$. Pulse was not palpable for $11 \mathrm{sec}$, after shock. Patient became moderately cyanotic during the clonic convulsion. Elevated $\mathrm{P}$ and $\mathrm{T}$ waves and tachycardia for next 37 sec. Then normal record except for 4 ventricular extrasystoles during following $28 \mathrm{sec}$. Norma] record thereafter. 
of shorter duration than those seen in the unpremedicated patients. The duration of the tonic phase of the convulsion particularly was shorter in this group. When the action currents of the clonic seizure decreased, various arrhythmias could be discerned. These included sinus arrhythmia, tachycardia, bradycardia, sinoauricular block, atrioventricular nodal rhythm, shifting pacemaker, and auricular and ventricular extrasystoles. $\mathbb{P}$ - and $\mathrm{T}$-wave elevation occurred most frequently. $\mathrm{T}$-wave depression or inversion occurred only six times. Tachycardia was seen far more frequently than bradycardia during and after the clonic seizure of the grand mal convulsion. (Figs. 1-5). Following nineteen of the thirty-one abortive convulsions, bradycardia was the main alteration observed. Eight of the other twelve had no disturbance, and the other four had a moderate tachycardia. These arrhythmias were essentially the same as reported by others (13-19).

Methantheline was discontinued as a premedicant after the first eight treatments, as the patients complained of palpitation. Promethazine and mepazine were not as effective in reducing the cardiovascular reactions and were also discontinued after twenty-one and nineteen treatments respectively. The remaining five drugs appeared to produce a similar reduction in electrocardiographic"disturbances, but none completely abolished these. The latter could probably be extended by increasing the dose of the drugs, but intense drying of salivary secretions was very disturbing to these patients, and was therefore avoided.

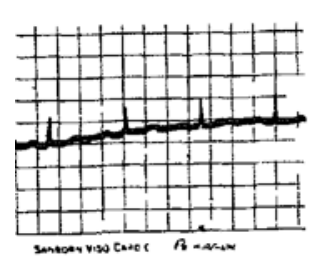

CONIROL
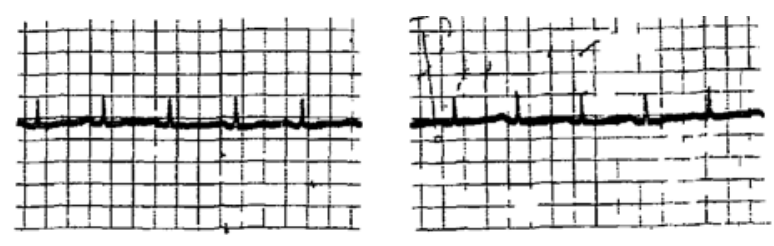

5 manuive of 0 3ng bilictoline

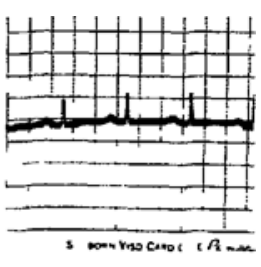

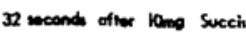

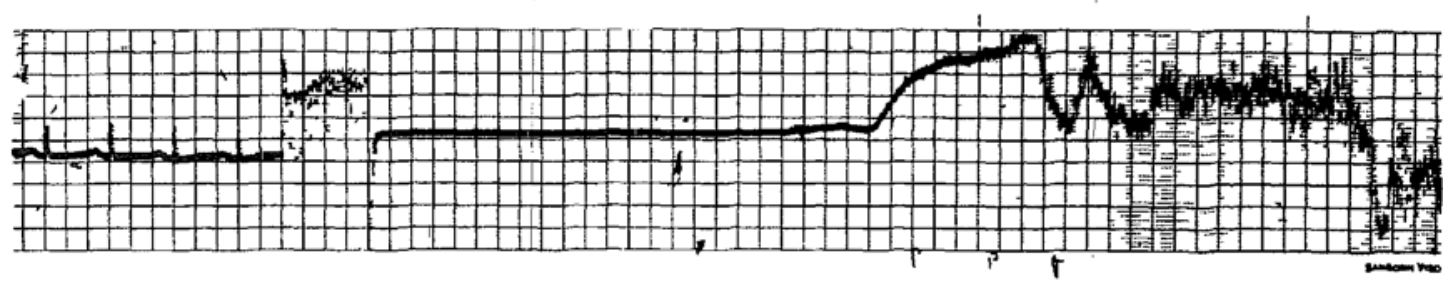

19 monte

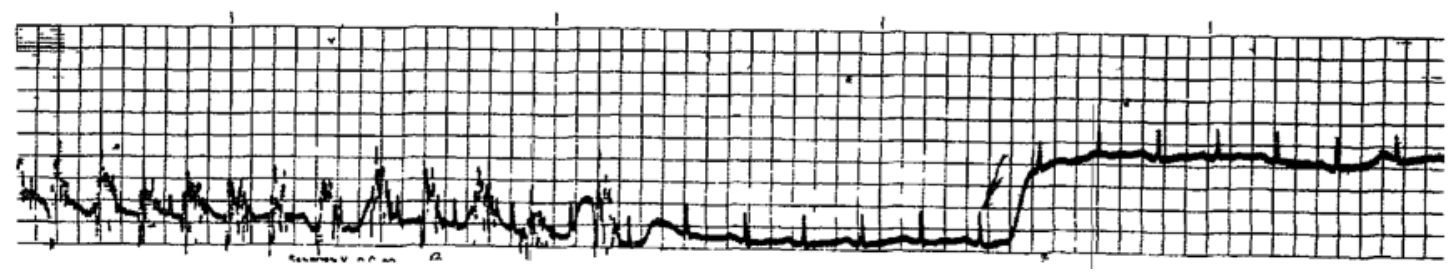

Figure 3. Same patient as in Figures 1 and 2, 2 days later. Premedicated with $0.3 \mathrm{mg}$. bellafolne i v. Modified ECT with $115 \mathrm{v}$. for 09 sec. No cyanosis developed during the convulsion Pulse was not palpable for 5 sec. after shock. Elevated $P$ and $T$ waves, but no tachycardia for $28 \mathrm{sec}$. Normal record thereafter. 


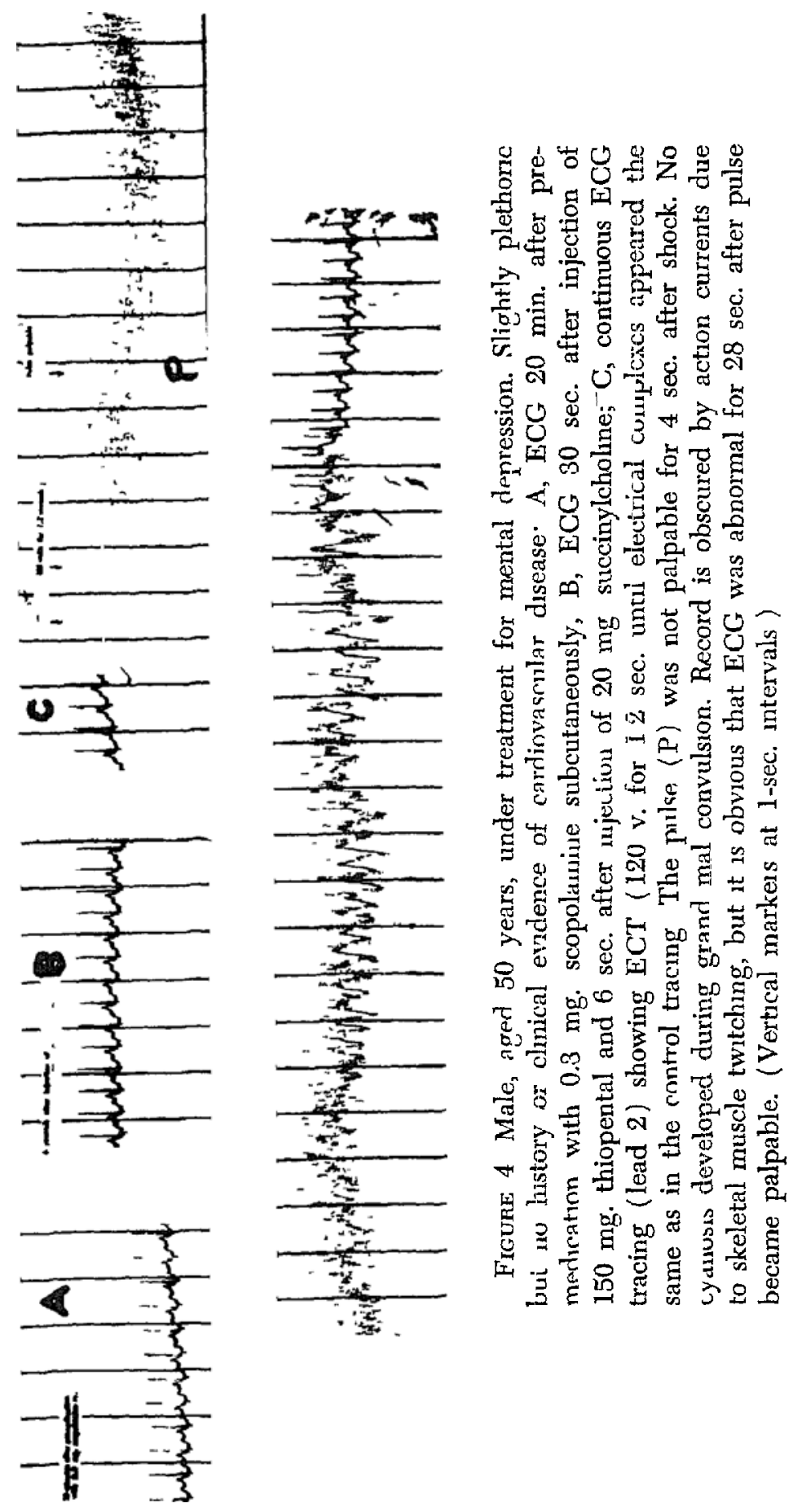




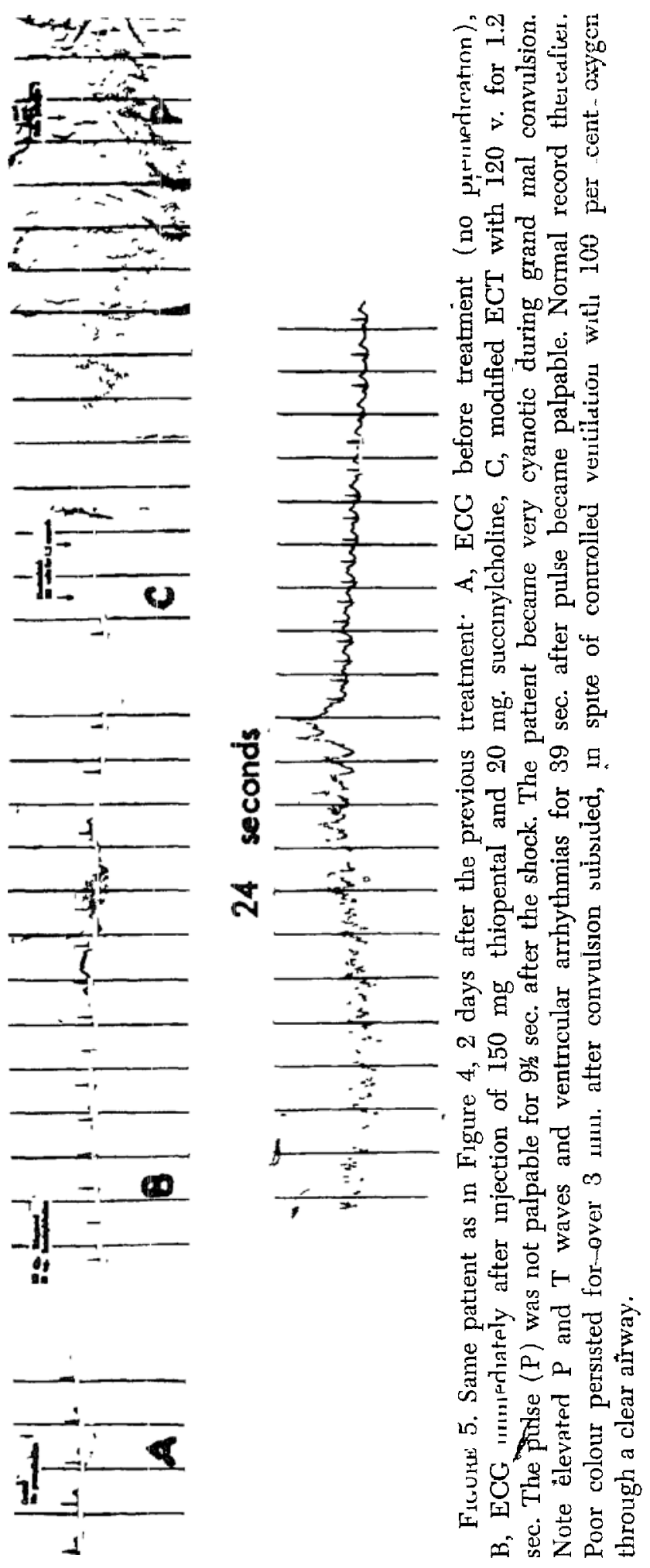




\section{Discussion}

ECT usually causes four acute changes in the patient: (i) loss of consciousness; (ii) a convulsion; (iii) an autonomic syndrome affecting the respiration, the rate and rhythm of the heart, the blood pressure, the sphincters of the genital-urinary tract, the pupils, the salivary glands, and gastric secretion; and (iv) a number of ill-defined endocrine and metabolic alterations which affect the level of blood glucose, proteins, lipoids, chloride, calcium, nitrogen, phosphorus (increased), and potassium (decreased) $\cdot(20)$.

Many of these changes are similar to those seen when the hypothalamus is stimulated. Neurophysiologists believe that this region of the brain is the centre of primordial emotional life. Electroshock, therefore, appears to cause excitation of the centres of the autonomic nervous system and is accompanied by upward discharge from the hypothalamus to the cortex (21-22).

The significance of transitory electrocardiograph changes are often discounted during stress reactions. However, when they are accompanied by such a severe physical reaction as occurs during ECT, they must not be ignored-especially in the elderly patient with or without clinical evidence of cardiovascular disease. The clinical disappearance of the pulse and heart sounds during the tonic phase of ECT in many of the patients may indicate a very sharp fall in cardiac output due either to a precipitous reduction in stroke volume, or to complete diastolic arrest. The elevated $\mathrm{P}$-wave which was seen most frequently during the clonic convulsion is probably indicative of dilatation of the auricle as the heart continues to fill during ineffectual ventricular contraction; and the sinus tachycardia, which was seen so frequently, is probably caused by a Bainbridge-type of reflex, (15).

Since ECT does not remove any primary causes of mental diseases, and may only alter their mechanisms, it has become an established therapeutic procedure for only certain mental disorders, because it produces results better than other forms of shock therapy, and is probably much safer (12). But, as Maclay has pointed out, the annual death rate from ECT is increasing, and the total number of deaths is considerable when one thinks in terms of individuals and not of statistics and percentages (23). Therefore, it must be recognized that the repeated administration of ECT may produce pathological disturbances which acutely threaten the life of the patient.

The main concern of the anaesthetist and the psychiatrist during the administration of ECT is the avoidance of acute pathological changes in cardiorespiratory function. It is now evident that unmodified electroshock and modified electroshock in the unpremedicated mental patient causes a serious disturbance of cardiac dynamics. These disturbances are reduced by premedication with a therapeutic dose of an anticholinergic drug, or a potent antihistaminic drug $(18,24-26)$. They may be abolished by somewhat larger doses of some of these drugs, such as: atropine $2 \mathrm{mg}$., scopolamine $0.8 \mathrm{mg}$., lhyoscyamine $1 \mathrm{mg}$., oxyphenonium $1 \mathrm{mg}$,, or hexocyclium $3 \mathrm{mg}$.

Several questions could not be answered from these clinical studies, and they have not been investigated by previous workers. I believe that these require an unequivocal answer before further improvement in the care of mental patients 
undergoing ECT can be sought. (i) Does the heart actually stop at some time during ECT? (ii) If so, is this due to the effect of electroshock on the higher centres of the brain, or a vagal-carotid sinus syndrome, or a period of complete heart block such as occurs in. Stokes-Adams syndrome? The latter effect is quite possible since stimulation of the carotid sinus may occur during the tensing of the neck muscles during the tonic phases of ECT, producing either a vagal or a vasodepressor response. The former may cause reflex slowing of the heart because of sinus node inhibition or atrioventricular block. The latter may cause hypotension only. (iii) Do thiopental and succinylcholine protect the patient from undesirable cardiorespiratory reactions? Gellhorn believes that barbiturates abolish the effectiveness of ECT in that it no longer elicits a pressor response, as seen in unanaesthetzzed patients, but elicits a depression of blood pressure owing to the predominance of the parasympathetic or vagal excitation (27). Others feel that modifying ECT does not reduce its efficacy anc does protect the patients' cardiovascular system from severe and acute alterctions (17, 18, 28-30). (iv) If asystole does occur, can it be avoided entirely by previous administration of a vagal-blocking dose of an anticholinergic drug or a potent antihistaminic drug?

A series of animal studies were undertaken to answer the above questions, and will be described in a later report.

\section{Summary and Conclusions}

The effect of anticholinergic drugs on the cardiac vagus was studied by means of monitoring the electrocardiogram (lead 2), the radial pulse (palpation), and the apical heart beat (auscultation) in 66 mentally disturbed patients before, during, and after 396 unmodified and modified electroshock treatments. It was suspected, but could not be demonstrated unequivocally, that a period of cardiac asystole occurred when no anticholinergic drug was given. Premedication with an anticholinergic drug reduced potentially dangerous cardiac arrhythmias that followed ECT .

If asystole does indeed occur durfng ECT, it should be considered essential to premedicate every patient with an anticholinergic drug in sufficient dosage to block the cardiac vagus, especially if there is suspicion or evidence' of cardiovascular disease.

\section{ACKNOWLEDGMENT}

I sincerely appreciate the co-operation, continuous intereśt, and invaluable assistance of the entire stafl in the Department of Psychiatry, University Hospital, Saskatoon, under Dr. McKerracher and Dr. Coburn during this study.

\section{RÉSUMÉ}

Chez 66 malades souffrants de désordres mentaux à qui nọus avons domné 396 électrochocs modifiés et non modifiés, nous avons étudié avant, pendant et après les traitements, l'effet de médicaments anticholinergiques sur le vague cardiaque, 
en sonorisant l'électrocardiogramme (en 2ème dérivation), en palpant le pouls radial et en auscultant le bruit cardiaque de la pointe. Des arrythmies d'origine vagale ont été observées dans la plupart des cas. A l'électrocardiogramme, nous avons noté fréquemment une élévation de l'onde $\mathrm{P}$ au cours de la convulsion. clonic ue, ce que nous avons interprété comme une indication de la dilatation de l'oreilette continuant à se remplir durant des contractions ventriculaires inefficaces. Nous avons également observé, à maintes resprises, de la tachycardie, signature d'un réflexe du type Bainbridge.

Nous avons soupçonné, sans pouvoir le démontrer de façon non équivoque, qu'il apparaissait une période d'asystolie cardiaque lorsque nous n'avions pas administré, au préalable, de médication anticholinergique. La confirmation de cet avancé est basée sur la constatation d'absence de pouls palpable à la radiale, d'absence de bruits cardiaques perceptibles à l'auscultation et de l'absence d'activité électrique cardiaque à l'électrocardiogramme. Nous avons entrepris, chez l'animal, une série d'expériences dans le but d'approfondir cette étude.

$\mathrm{Si}$, en réalité, il se produit une asytolie au cours de l'électrochoc, il s'imposerait en conséquence que tous les malades, et plus particulièrement ceux chez qui l'on soupçonne des lésions cardiovasculaires et ceux qui sont porteurs de semblables lésions, que tous les malades reçoivent une prémédication contenant des médicaments anticholinergiques en quantité suffisante pour inhiber le vague /cardiaque.

\section{REFERENCES}

1. Dobkin, A. B, Wyant, G M, \& Aashem, G. M Antisıalogogue Drugs m Man Comparison of Some Anticholinergic and Sedative-antibistaminic Drugs Anaesthesid 13: $63(1958)$.

2. Bellet, S, Kershbaum, A., \& Furst, W. The Electrocardiogram during Electroshock Treatment of Mental Disorders. Am J. M Sc 201167 (1941).

3. Altschule, M. D., \& Tillotson, K. J. Mechanisms underlying Pulmonary and Cardiac Complications of Electrically Induced Convulsions. New England J. Med. 238. 133 (1948).

4 Altschure, M. D. Further Observations on Vagal Influences on the Heart during Electroshock Therapy for Mental Disease. Am. Heart J. 3988 ( 1950 ).

5 Jetren, W. W. Fatal Circulatory Fallure Caused by Electric Shock Therapy Arch Neurol. \& Psychiat. 51. 557 (1944)

6. Krтchivg, E. H. Physical Disability and Electroconvulsion Therapy. Lancet 21305 (1954).

7. McKnicht, W. K., Burbnidge, R., \& Guth, P. Electroconvulsive Therapy in the Presence of Physical Defects. J. Nerv. \& Ment. Dis. 119: 478 (1954).

8. Crowley, P. J. Cardiac Arrest following Electropexy. Lancet 1. 376 (1958).

9. DoвkIN, A. B. Cardiac Arrest following Electropexy. Lancet 1: 640 (1958).

10. Silfverskiold, B. P, \& Amark, C Disturbances of Circulation in Convulsions of the Eple stıc Type. II, Arterial and Venous Pressure during Electroshock. Acta med. Scancinav. 113: 191 (1943).

11. Wricox, P. H. The Electroshock Convulsion Syndrome. Amı. J. Psychiat. 100. 668 (1944).

12. Barrera, S. E., \& Kalinowsky, L. B. Electric Shock Therapy in Mental Disorders. Med. Physics 1: 335 (1944).

13. Altschule, M. D., Sulzbach, W. M., \& Tillotson, K. J. Significance of Changes in the Electrocardiogram after Electrically Induced Convulsions in Man. Arch. Neurol \& Psychiat. 58 716 (1947). 
14. Bmoggia, H., Brage, D., \& VAyo, J. M. Cambios electrocardıgráficos durante el deencéfaloshock (Electrocardıgraphic Changes during Diencephalon Shock). Día Médico 28. 1453 ( 1956 ).

15 Hejtmancik, M R, Bafklf ad, A. J, \& Herrmann, G. R. Electrocardiographic Changes following Electroshock Therapy in Curarized Patients. Am. Heart J. 37.790 (1949).

16 Kline, E. M., \& FetTerman, J. L. Electrocardıgraphic Changes following Electrically Induced Convulsions. Am Heart J. 24: 665 (1942)

17 Ровот, M, \& Bisquerra, E. Cardiopathies electro-chocs et succinyl-choline. Presse méd. 641101 (1956).

18 Richardoson, D. J, Lewis, W H, Gahagan, L H., \& Shrehan, D. Etiology and Treatment of Cardiac Arrhythmias under Anaesthesia for Electroconvulsive Therapy. New York State J. Med 57881 (1957).

19. Von NymaN, E, \& Silfverskiolo, B P. Krelslaufstorungen bei Krampfanfallen epilept1schen Typs III, Das Electrokardıogram beim Elektroschork. Acta med Scandinav. 114. 223 (1943)

20 Delay, J L'Electro-choc et la psycho-physiologie. Pars Masson et Cie (1946).

21 Cerlettr, U. Old and New Information about Electroshock Am J. Psychiat. 10787 (1950).

22 Gelithorn, E. Analysis of Autonome Hypothalamic Functions in the Intact Organism. Neurology 6 335 (1956).

23. MACLAY, W. S. Deaths due to Treatment. Proc. Roy Soc. Med. 46.13 (1953).

24. Lonergan, L II, \& Gruber, C M. The Blocking Action of Antihistaminic Drugs on the Cardiac Vagus Nerve in the Terrapin. Arch internat de pharmacodyn. et de thérap. 112. 381 (1957).

25 Bankmead, A J ! Torrens, J. K, \& Harrts, T. H. Anticipation and Prevention of Cardiac Complications in Electroconvulsive Therapy. Am. J Psychiat. 106911 (1950)

26 Hayman, $M$ The Prophylaxis of Cardiac Complications in Electroshock Therapy. Am J. Psychiat. 102316 (1945-6).

27 Gellmorn, E Physiological Foundations of Neurology and Psychuatry, p. 380 Minneapolis Univer Minnesota Press (1953).

28 Montagu, J D, The Modification of Convulsion Therapy by Muscle-Relaxant Drugs. Acta psychiat. et neurol Suppl 87 (1953)

29 NowiLl, W. K, WIIson, W, \&'Bondens, R Succinylcholne Chlonde in Electroshock Therapy 2, Caudrovascular Reactions A M A. Arch Neurol. \& Psychiat. 71. 189 (1954).

30 Wilson, W P, Hickam, J B, Nowill, W. K, \& Frayser, R Succinylcholine Chlonde in Electroshock Therapy 3, Oxygen Consumption and Arterial Oxygen Saturation. A M. A Arch. Neurol. \& Psychuat 72550 (1954) 